\title{
Extensive complex odontoma in the maxillary sinus: An uncommon presentation as a cause of chronic sinusitis
}

\section{Extenso odontoma complexo em seio maxilar: Uma apresentação incomum como causa de sinusite crônica}

\begin{abstract}
Purpose: This study reports a case of a extensive odontoma causing maxillary sinusitis.

Case description: A 25-year-old man at clinical examination revealed discrete facial asymmetry and exposure of the lesion in the oral cavity. Imaging exams showed the presence of a well-defined radiopaque mass in the left maxilla, measuring approximately $7 \mathrm{~cm}$ and was intimately associated with the maxillary sinus and oral cavity. The mass was excised through an intraoral access under general anesthesia in the hospital and sent for histopathology, which was diagnosed as complex odontoma. The patient is under clinical follow-up and shows no signs of maxillary sinusitis and no oral sinus fistula.

Conclusion: The odontoma is a common injury in clinical dentistry, but in some aggressive cases may cause sequelae in the patient, thus, caution the dentist for proper diagnosis and treatment.
\end{abstract}

Key words: Complex odontoma; odontogenic tumour; maxillary sinus

\section{Resumo}

OBJETIVO: Este estudo relata a apresentação de um extenso odontoma causando sinusite maxilar.

DESCRIÇÃO DO CASO: Um homem de 25 anos ao exame clínico revelou assimetria facial discreta e exposição da lesão na cavidade oral. Os exames de imagem mostraram a presença de uma massa radiopaca bem definida na maxila esquerda, medindo aproximadamente $7 \mathrm{~cm}$ e estava intimamente associado com o seio maxilar e a cavidade oral. A massa foi extirpada através de um acesso intra-oral, sob anestesia geral em ambiente hospitalar e enviada para estudo histopatológico, onde foi diagnosticada como odontoma complexo. O paciente está sob acompanhamento clínico e não mostra sinais de sinusite maxilar e fístula bucossinusal. CONCLUSÃO: O odontoma é uma lesão comum na clínica odontológica, mas pode, em alguns casos, se apresentar de forma agressiva levando a danos ao paciente, e desta forma, é necessária atenção do cirurgião dentista para o correto diagnóstico e tratamento.

Palavras-chave: Odontoma complexo; tumor odontogênico; seio maxilar

\author{
Cyntia Helena Pereira de Carvalho ${ }^{\circ}$ \\ Diego do Amaral Costa ${ }^{b}$ \\ Lélia Maria Guedes Queiroz"a \\ José Ivo Q. do Amaral b \\ Adriano Rocha Germano b \\ - Department of Oral Pathology, Federal University \\ of Rio Grande do Norte, Natal, RN, Brazil \\ b Department of Oral and Maxillofacial Surgery, \\ Federal University of Rio Grande do Norte, Natal, \\ RN, Brazil
}

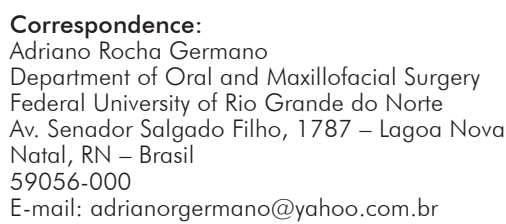

E-mail: adrianorgermano@yahoo.com.br

Received: October 28, 2010

Accepted: January 28, 2011

Conflict of Interest Statement: The authors state that there are no financial and personal conflicts of interest that could have inappropriately influenced their work.

Copyright: (C) 2011 Carvalho et al.; licensee EDIPUCRS. This is an Open Access article distributed under the terms of the Creative Commons AttributionNoncommercial-No Derivative Works 3.0 Unported License. 


\section{Introduction}

The term "odontoma" was introduced by Broca in 1863 to comprise all benign odontogenic tumors. At present, odontomas are classified by the World Health Organization as mixed benign odontogenic tumors because of their origin from epithelial and mesenchymal cells, exhibiting different structures of dental tissue (enamel, dentin, cementum and pulp) (1). Because of their slow progression, some investigators do not believe in the tumor characteristics of odontomas since they follow mechanisms similar to those observed during odontogenesis, i.e., their growth ceases once the process of calcification is completed $(2,3)$.

Odontomas are considered to be the most common odontogenic tumors of the jaw bones and may appear as numerous miniature or rudimentary teeth, called compound odontomas, or as an amorphous mass of mineralized tissue (complex odontomas) (3).

The etiopathogenesis of odontomas has been extensively studied but continues to be not completely established. The most accepted etiology is related to trauma, infection, growth pressure, and genetic mutations in one or more genes that cause disturbances in the mechanism controlling tooth development $(1,3)$. Sinusitis of dental origin is a relatively frequent disease and is caused by periapical abscesses that extend to the maxillary sinus or by secondary infections of oral sinus fistulae resulting from tooth extraction. Cases of sinusitis resulting from an odontoma in the maxillary sinus are rare (4).

This paper reports a clinical case of complex odontoma in the maxillary sinus as a cause of chronic sinusitis lasting for years.

\section{Description of the case}

A 25-year-old man was seen at the Surgery and OralMaxillofacial Traumatology Service, Department of Dentistry, Federal University of Rio Grande do Norte, Natal, RN, Brazil, with a history of facial pain and swelling. Two years earlier, the patient had undergone a procedure performed by a medical professional specialized in otorhinolaryngology which, however, did not result in the improvement of symptoms. The patient had suffered from maxillary sinusitis for 4 years, with negative repercussions on his general health. Unilateral nasal obstruction, fetid breath and the presence of purulent secretion during sinusitis crises, which regressed after the administration of antimicrobial agents, were observed.

Intraoral physical examination clearly showed the presence of a hardened yellowish mass associated with the absence of the posterior molars on the corresponding side (Fig. 1).

Panoramic radiography revealed the presence of a radiopaque mass in the left maxilla extending from the alveolar ridge to the maxillary sinus (Fig. 2). Computed tomography showed an extensive mass in the left maxillary sinus, which was intimately associated with the oral cavity and an impacted tooth and practically occupied the entire maxilla on that side (Fig. 3).

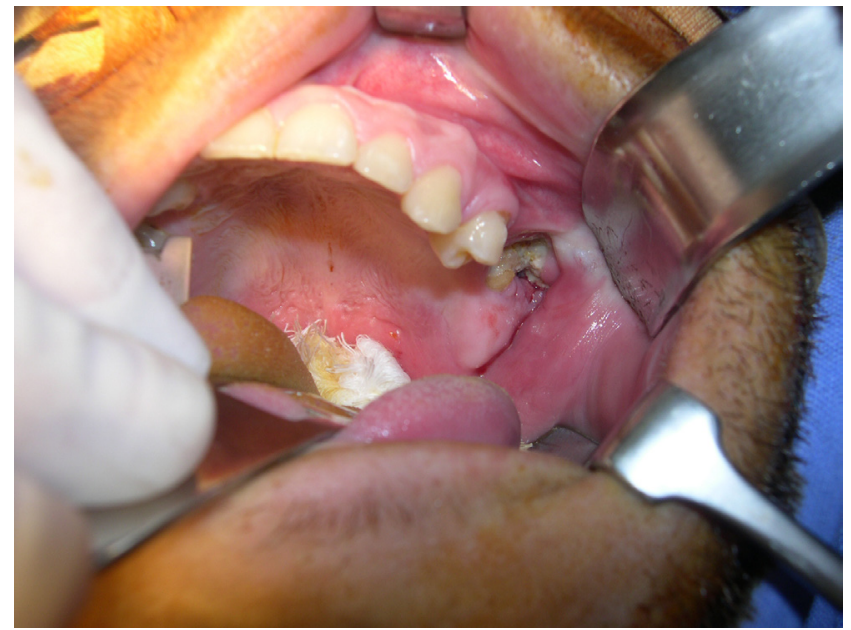

Fig. 1. Intraoral view showing a hard yellowish mass associated with the absence of the posterior molars.

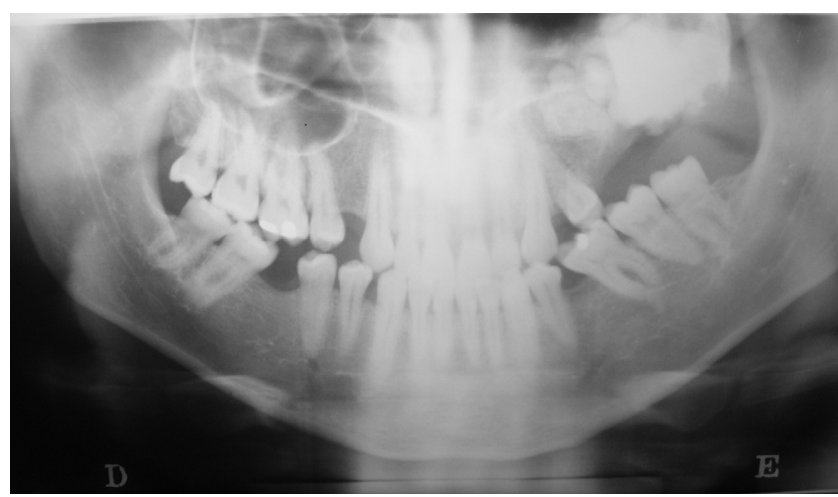

Fig. 2. Preoperative panoramic radiograph showing a mass in the left maxillary sinus.

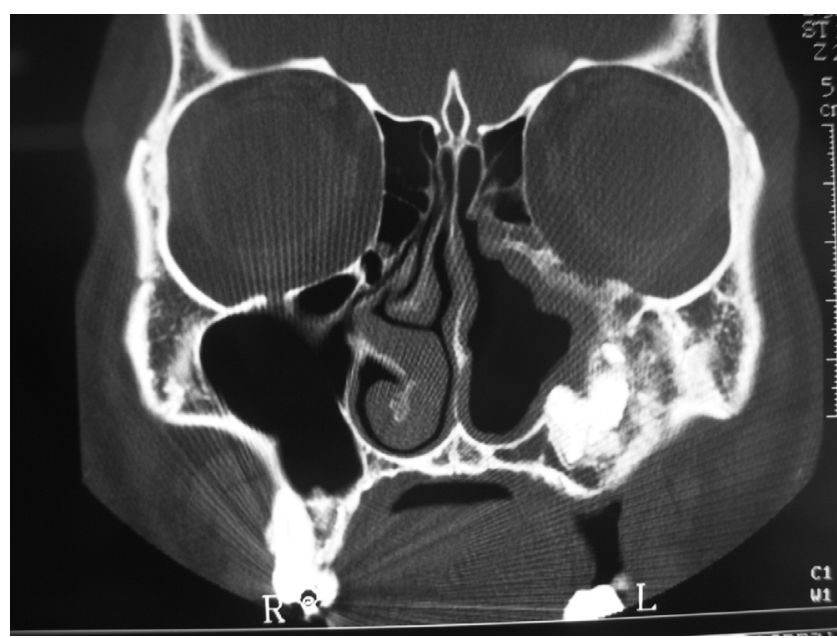

Fig. 3. Coronal CT with bone windows demonstrating a mass in relation to the maxillary sinus and oral cavity. 
The clinical and radiographic diagnosis was compatible with odontoma, which favored the occurrence of symptoms of maxillary sinusitis due to exposure of the lesion to the oral environment. Antibiotic therapy consisting of the combination of amoxicillin and clavulanic acid, the drugs of choice at our institution, was started, followed by the use of a topical nasal decongestant. Once the clinical condition of the patient was stabilized, he was submitted to excision of the lesion through an intraoral access under general anesthesia. After detachment of the flap, an osteotomy was made around the mass to facilitate removal of the odontoma. After excision, the maxillary sinus was curetted and a nasal counter-opening was made. The material was then sent for histopathological analysis. The oral fat pad graft facilitated primary closure of the surgical wound, minimizing the risk of dehiscence and the consequent occurrence of an oral sinus fistula.

Histopathological analysis showed an irregular arrangement of dental tissues such as enamel, dentin and cementum, together with odontoblastic cells in pulp tissue, findings that confirmed the diagnosis of complex odontoma (Fig. 4).

The postoperative follow-up was satisfactory, with the patient developing no oral sinus fistula and showing no signs of maxillary sinusitis (Fig. 5).

Fig. 4. Photomicrograph of the odontoma showing an irregular arrangement of dentin, enamel matrix, cementum and pulp-like connective tissue, H.E. $(200 \times)$.

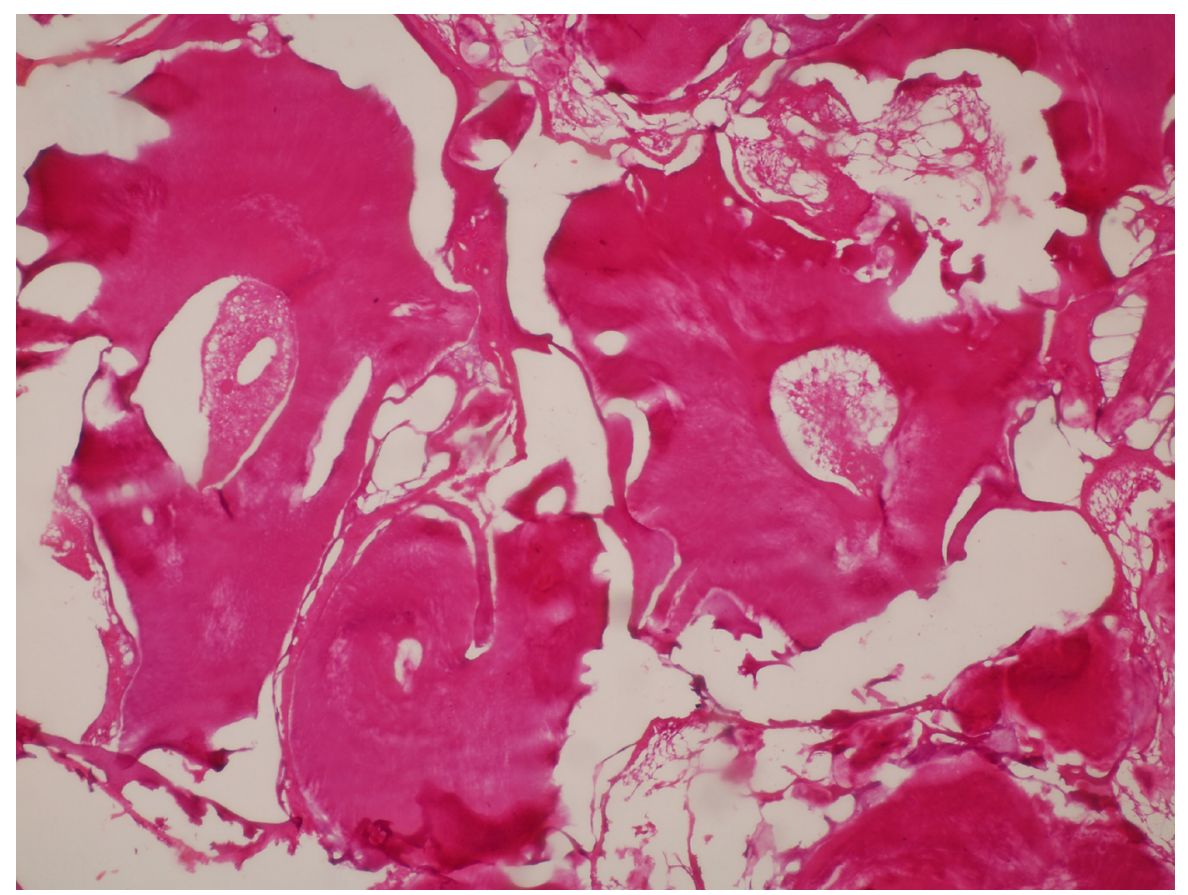

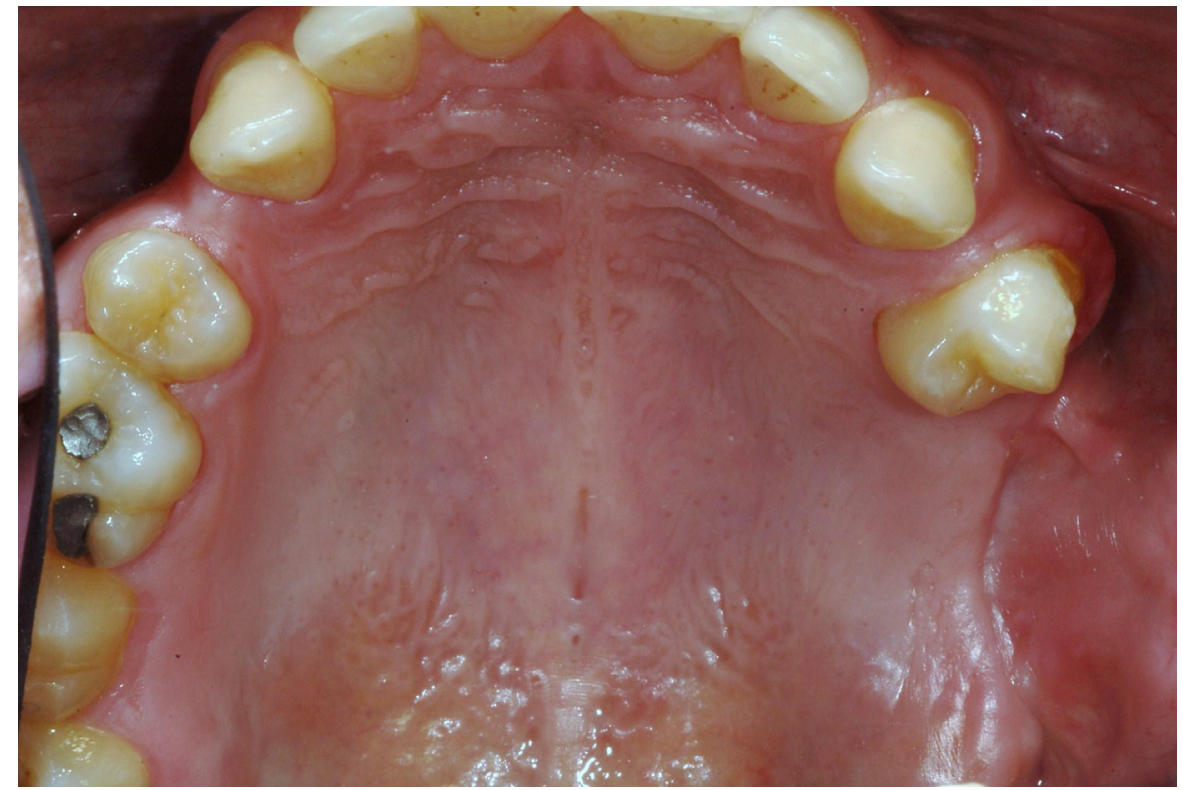

Fig. 5. Good intraoral clinical aspect after surgery. 


\section{Discussion}

Odontoma is a generally asymptomatic, slowly progressing tumor that may pass unnoticed $(5,6)$. The presence of odontomas may cause a series of disorders and sequelae in the patient, such as problems related to their interference with the process of tooth eruption, ectopic eruption, displacement and malformation of adjacent teeth, diastema, anodontia, and growth pressure exerted by the odontoma that may cause pain, devitalization, and tooth and bone resorption $(2,7)$. In the present study, the patient presented sequelae, including the absence of the permanent posterior teeth important for occlusion, as well as significant bone loss which even became more marked after removal of the tumor.

Complex odontomas generally reach diameters ranging from several millimeters to 3-4 cm (8). These odontomas preferentially involve the posterior portion of the jaw and might be associated with an unerupted or absent tooth in the region $(3,9)$. The present case of complex odontoma can be considered to be rare because of its large size (approximately $7 \mathrm{~cm}$ in diameter), in addition to its atypical location, occupying the posterior region of the maxilla.

Caboc et al. (10) reported that odontomas in the maxillary sinus may cause pain, facial asymmetry and chronic congestion of the sinus. This was observed in the present case in which the odontoma caused marked discomfort to the patient due to the communication between the sinus and oral cavity caused by exposure of the tumor. This fact favored maxillary sinusitis due to the continuous communication between the two cavities.
The radiopaque image of complex odontomas in the maxillary sinus can be characteristic of various bone lesions such as cementoblastomas, osteomas, ossifying fibromas, and osteoblastomas, as well as of other odontogenic tumors such as calcifying epithelial odontogenic tumors and ameloblastic fibro-odontomas $(8,9)$. The presence of welldefined borders and a radiolucent halo around the radiopaque mass is a characteristic finding of odontoma, which was observed in the present case and confirmed by histopatho$\log$.

Complex odontomas can be associated with other more aggressive odontogenic lesions such as cysts and tumors Thus, there is consensus in the literature that, once detected, odontomas should be surgically removed $(7,10)$. In the present case, the indication for surgery was based on the presence of sinus infection and the need for oral rehabilitation of the edentulous area. However, no pathologic lesions associated with the odontoma were observed. The decision of removing the tumor under general anesthesia in the hospital was based on the extent of the mass and the need for maxillary sinus treatment after excision.

Odontomas are common tumors that can be easily diagnosed and treated. However, these tumors should not be underestimated since they may show rare and aggressive features that can lead to serious disorders in the patient. This was the case here, with the patient presenting maxillary sinusitis caused by a complex odontoma, which was diagnosed after clinical and imaging evaluation and confirmed by histological analysis.
References
1. Aiike SO, Adekeye EO. Multiple odontomas in the facial bones. A case report.Int J Oral Maxillofac Surg 2000 :29:443-4.

2. Singer SR, Mupparapu M, Milles M, Rinaggio J, Pisano D, Quaranta P. Unusually large complex odontoma in maxillary sinus associated with unerupted tooth. Report of case and review of literature. NY State Dent J 2007:73;51-3.

3. Sánchez OH. Berrocal MIL, González JMM. Metaanalysis of the epidemiology and cinical manifestations of odontomas. Med Oral P Patol Oral Cir Bucal 2008:13;730-4.

4. López M, Monserrat JR, Kolanczak K, Piñeioro Z, Gañan L, Costey M. Sinusitis odontógena y fístula orosinusal. Rinitis, rinosinusitis, poliposis nasal. Ponencia Oficial de la SEORL y PCF, 2005. Badalona. EUROMEDICE Ediciones Médicas 2005:721-30.

5. Crespo Del Hierro J, González MR, Portela MD, García del Castillo E, Serrano JC. Odontoma compuesto como causa de sinusitis maxilar crônica. Acta Otorrinolaringo Esp 2008:59;359-61.

6. Hisatomi M, Asaumi JI, Konouchi Honda Y, Wakasa T, Kishi K. A case of complex odontoma associated with an impacted lower deciduous second molar and analysis of 107 odontomas. Oral Dis 2002:8;100-5.

7. Sales MA, Cavalcanti MG. Complex odontoma associated with dentigerous cyst in maxillary sinus: case report and computed tomography features. Dentomaxillofac Radiol 2009;38:48-52.

8. Lee $\mathrm{CH}$, Park GJ. Complex and compound odontomas are clinico-pathological entities. Basic Appl Pathol 2008;1:30-3.

9. Tomizawa M, Otsuka Y, Noda T. Clinical observations of odontomas in Japanese children: 39 cases including one recurrent case. Int J Paediatric Dent 2005;15:37-43.

10. Cabov T, Krmpotic M, Grgurevic J, Peric B, Jokic D, Spomenka Manojlovic S. Large complex odontoma of the left maxillary sinus. Wien Klin Wochenschr 2005;1 17/21 . $22,780-3$. 